\title{
Policy Analysis on The Implementation of The Posyandu Lansia Program: Study at Puskesmas Jua Gaek Sub-District Gunung Talang of Solok Regency of West Sumatera
}

\author{
Yulia Roza ${ }^{(1)}$, Lince Magriasti ${ }^{(2)}$ \\ \{ 01 yuliarza@gmail.com ${ }^{(1)}$, lincemagriasti@ fis.unp.ac.id ${ }^{(2)}$ \}
}

Public Administration Department of Social Science Faculty of Universitas Negeri Padang

\begin{abstract}
The increase in the number of elderly people with a percentage of about 9.6 percent in the period 1971-2019 or around 25 million more Indonesians were also followed by an increase in households inhabited by the elderly are 27.88 percent and 61.75 percent of being household heads. The government's task in the population sector is to carry out the posyandu lansia program with the aim of ivmproving the quality of families including elderly families which is carried out by all Puskesmas based on the Minister of Health Regulation No. 67 of 2015. Low participation of elderly in posyandu lansia Program because of the fear of knowing their illness or lack socialization about implementation program and then limited health workers are some problems in the implementation of the posyandu lansia program especially at Puskesmas Jua Gaek in Solok Regency of West Sumatera. The working area of the Puskesmas Jua gaek consists of nine jorong areas With the structure of the rural area and the majority of the population are a farmer that makes the posyandu lansia program was not maximum and fully followed by the elderly population. Although the implementation of the posyandu lansia program is still carried out regularly every month, there is no significant increase in the number of elderly people to participate. Even though the implementation of this program is included in the routine budget of puskesmas Jua Gaek. The condition of the Covid-19 pandemic also affects the implementation of the posyandu lansia program although it is still carried out every month but on implementation the health worker still working face to face with the elderly. The problem is whether the implementation of the posyandu lansia program could improve the quality of life of the elderly when the participation of the elderly is minimal?. This paper answers these questions and at the same time provides an alternative choice of implementing the elderly posyandu program by making a schedule to picking up the elderly.
\end{abstract}

Keywords: policy analysis, elderly posyandu, Puskesmas Jua Gaek.

\section{Introduction}

Development in the health sector needs to be done because health is very important in living life and is the right of everyone to get health services. Health service is a form of effort undertaken to serve the community wholeheartedly and strive to assist the community in 
improving their health, regardless of status between the rich and the poor, race, religion, ethnicity, politics. All must get the same health service regardless of age, including the elderly who need health services in their old age to improve the health status of the elderly themselves [1].

The health of the elderly today cannot be ignored because Indonesia is going through an aging population phase in which there is a decrease in the fertility rate followed by an increase in life expectancy. Based on data from the Central Bureau of Statistics (BPS), in 2010 Indonesia had a population of 18 million elderly with a percentage of $7.56 \%$. In 2019, this percentage increased to $9.7 \%$ with a population of 25.9 million and is estimated to continue to increase in 2035 by 48.2 million with a percentage of $15.77 \%$ [2].

The increase in the elderly population is the basis for the government in determining the outline of policies and programs for the elderly that can increase life expectancy and the quality of health of the elderly. The program aimed at the elderly population is the posyandu for the elderly. The posyandu program for the elderly is a program that is implemented by puskesmas as regulated in the Regulation of the Minister of Health of the Republic of Indonesia Number 67 of 2015 concerning the Implementation of Elderly Health Services at Community Health Centers (Puskesmas).

From the data of the Indonesian Family Health Directorate, in 2018 Indonesia there were 4,835 health centers out of 9,993 health centers that have implemented health care services for the elderly with a percentage of $48.4 \%$ and already have 100,470 elderly posyandu. One of them is West Sumatra, there were 116 PKM (Community Health Services) for the elderly with 2054 elderly posyandu spread across 19 districts/cities including Solok Regency. In Solok District, there are 16 PKM with elderly polite and 77 posyandu for the elderly. The following can be seen in table 1 regarding the number of elderly posyandu in Solok Regency:

Table 1 Number of Elderly Posyandu in Solok Regency

\begin{tabular}{cllc}
\hline No & \multicolumn{1}{c}{ Sub-District } & \multicolumn{1}{c}{ Name of Puskesmas } & $\begin{array}{c}\text { Number of The Elderly } \\
\text { Posyandu }\end{array}$ \\
\hline 1 & Pantai Cermin & Surian & 2 \\
2 & Lembah Gumanti & Alahan Panjang & 3 \\
3 & Hiliran Gumanti & Talang Babungo & 3 \\
4 & Payung Sekaki & Sirukam & 5 \\
5 & Tigo Lurah (Bajanjang) & Batu Bajanjang & 0 \\
6 & Lembang Jaya & Bukit Sileh & 1 \\
7 & Danau Kembar & Simpang Tanjung Nan IV & 1 \\
8 & Gunung Talang & Jua Gaek & 9 \\
9 & Gunung Talang & Talang & 4 \\
10 & Gunung Talang & Kayu Jao & 3 \\
11 & Bukit Sundi & Muara Panas & 12 \\
12 & IX Koto Sungai Lasi & Sungai Lasi & 5 \\
13 & Kubung & Tanjung Bingkung & 5 \\
14 & Kubung & Selayo & 13 \\
15 & X Koto Diatas & Sulit Air & 0 \\
16 & X Koto Diatas & Paninjauan & 3 \\
17 & X Koto Singkarak & Singkarak & 2 \\
18 & Junjung Sirih & Paninggahan & 6 \\
\hline
\end{tabular}

Source: Ministry of Health of the Republic of Indonesia. Data Dasar

Puskesmas di Propinsi Sumatera Barat pada Desember 2018.

Jakarta: CV. Graphic Dwipa; 2018 
From table 1 it is known that 16 health centers in Solok Regency have organized the elderly posyandu and only 2 puskesmas have not implemented posyandu for the elderly, namely the Batu Bajanjang Community Health Center and the Hard Water Health Center. Based on table 1 above, it can also be seen that there are three health centers that have the most elderly posyandu, namely Puskesmas Selayo, Puskesmas Muara Panas, and Puskesmas Jua Gaek. Of the three health centers, the writer took one of the health centers as the focus of writing, namely the Jua Gaek Health Center with a policy analysis study of the implementation of the posyandu for the elderly in the Jua Gaek Puskesmas work area.The reason the authors chose the Jua Gaek Puskesmas Because the Jua Gaek Puskesmas is one of the puskesmas that has the most posyandu in Solok Regency, and the other reason is that the Jua Gaek Puskesmas is categorized into a puskesmas with a large number of elderly people. The number of elderly people can be seen in the following table

Table 2 The Number of Elderly Populations in the Work Area of the Jua Gaek Puskesmas, Gunung Talang District, Solok Regency, 2018-2019

\begin{tabular}{ccccccc}
\hline \multirow{2}{*}{$\begin{array}{c}\text { Age } \\
\text { Group }\end{array}$} & \multicolumn{3}{c}{ Man } & \multicolumn{2}{c}{ Women } & \multicolumn{2}{c}{ Total } \\
\cline { 2 - 7 } & $\mathbf{2 0 1 8}$ & $\mathbf{2 0 1 9}$ & $\mathbf{2 0 1 8}$ & $\mathbf{2 0 1 9}$ & $\mathbf{2 0 1 8}$ & $\mathbf{2 0 1 9}$ \\
$45-59$ & 884 & 940 & 956 & 1026 & 1840 & 1966 \\
$60-69$ & 478 & 478 & 533 & 533 & 1011 & 1011 \\
$>70$ & 240 & 240 & 329 & 329 & 569 & 569 \\
Total & $\mathbf{1 6 0 2}$ & $\mathbf{1 6 5 8}$ & $\mathbf{1 8 1 8}$ & $\mathbf{1 8 8 8}$ & $\mathbf{3 4 2 0}$ & $\mathbf{3 5 4 6}$ \\
\hline
\end{tabular}

Source : Data of Puskesmas Jua Gaek, 2019

From table 2 it is known that the number of elderly people with the age group of 45-59 years, 60-69 years, and 70 years and over in the Jua Gaek Puskesmas work area in 2018 and 2019. Based on data from the Jua Gaek Puskesmas as can be seen in Table 2 above, it is known that there is an increase in the number of elderly people in the 45-59 age group from 2018 to 2019 with an increase of 126 people or from 1840 people in 2018 and to 1966 people in 2019. The older an elderly person is, the population is getting decreasing, this can be seen in Table 2 that the number of the elderly population in 2018 is 1840 people in the $45-59$ years, while in the 6069 age group it is 1011 and the number decreases in the age group 70 years and over, namely 569 years. The same thing happened in 2019 , there was a decrease in the number of elderly people based on age groups. This condition makes many parties, especially the government, need to formulate policies and programs aimed at the elderly in developing the health of the elderly themselves .

Puskesmas of Jua Gaek has been holding posyandu for the elderly since 2018. The program is held in nine jorong in Nagari Cupak which is the working area of the Jua Gaek Puskesmas are Jorong Panyalai, Sungai Rotan, Balai Pandan, Balai Tangah, Tangah Padang, Aia Angek Sonsang, Pasar Baru, Pasar Usang, and Sawah Taluak. However, in implementation, there were many obstacles including the low participation of the elderly in the elderly posyandu program. Meanwhile, another obstacle is the lack of program socialization carried out by the puskesmas due to the low presence of the community in participating in the socialization, so that many elderly people do not know about the Posyandu Elderly program. Other problems that occur in the field are the low discipline of the elderly in participating in program implementation and the lack of frequency of implementing the posyandu for elderly people, which is only done once a month. 


\subsection{Theoretical study}

\section{Public Policy}

According to Woll, Tangkilisan (2003) cited in Taufiqurakhman that public policy is a government activity in solving problems that exist in society either directly or through institutions that affect people's lives. James E Anderson as cited by Islamy (2019) in Taufiqurakhman, public policy is a series of actions that have a specific purpose and are carried out and followed by an actor or a group of actors to solve certain problems.

In public policy there are several stages in the policy analysis, as stated by Taufiqurakhman [3] it can be seen as follows:

Table 3 Stages of Public Policy Analysis.

\begin{tabular}{ll}
\hline \multicolumn{1}{c}{ STAGES } & \multicolumn{1}{c}{ CHARACTERISTICS } \\
\hline Formulation of the problem & $\begin{array}{l}\text { Provides information about conditions that cause } \\
\text { problems }\end{array}$ \\
Forecasting & $\begin{array}{l}\text { Provide information about the future } \\
\text { consequences of policy implementation, including } \\
\text { if not making a policy } \\
\text { Provide information about the benefits of each } \\
\text { alternative and recommend policy alternatives that } \\
\text { provide the highest benefits. }\end{array}$ \\
Provide information about the current and \\
past consequences of implementing policy \\
alternatives including the constraints
\end{tabular}

\section{The legal basis for the Elderly Posyandu}

The Posyandu program for the elderly is one of the programs in the form of health facilities in the village / jorong aimed at improving the health of the elderly community. This program is implemented by the puskesmas by appointing several community members as cadres to organize the posyandu for the elderly. According to Kholifah, the targets of the elderly posyandu are among others [4]:

a. Direct Target

1) Pre-elderly group (45-59 years)

2) Elderly group (60 years and over)

3) High risk elderly group (70 years and over)

b. Indirect Target

1) Families where the elderly live

2) Social organizations engaged in the development of elderly people

3) The wider community

The direct targets of the elderly posyandu referred to here are groups or individuals in the community who are directly categorized due to age. Meanwhile, the indirect targets are groups or individuals outside the age group who are the direct targets of the elderly posyandu program.

The rate of growth of the elderly population from year to year has increased and is expected to continue to increase. This increase in the elderly population is the basis for the government in formulating policies and programs aimed at elderly population groups so that they can play a 
role in building public health. To improve the quality of elderly health services in health facilities, the Minister of Health Regulation Number 79 of 2014 concerning the Implementation of Geriatric Health Services in Hospitals has been issued into the National Hospital Accreditation Standard (SNARS) assessment since 2018 and Minister of Health Regulation Number 67 of 2015 regarding the Implementation of Elderly Health Services at Puskesmas. In addition, the Minister of Health Regulation Number 25 of 2016 concerning the National Action Plan for Elderly Health 2016-2019 was also issued to provide a reference for the central government, local governments, and other stakeholders. In the concrete steps that must be carried out on an ongoing basis in order to improve elderly health degree to achieve healthy, independent, active, and productive [5].

\subsection{Study}

\section{The Implementation of the Elderly Posyandu Program in the Jua Gaek Nagari}

The effectiveness of implementing a program can be measured through several indicators. There are several indicators that the authors use to measure the level of effectiveness of implementing the posyandu program for the elderly in the work area of Puskesmas Jua Gaek, namely measurement indicators which according to Sutrisno in Lestari \& Murti[6] there are five indicators, namely understanding of a program, being right on target, on time and achieving goals and there are whether or not real changes have occurred from the program's implementation.

First, understanding the program. Understanding of the program is very necessary, if a program is not understood it will result in decreased participation in the program, especially since the program is intended for the community. In the implementation of the posyandu for the elderly at the Jua Gaek Puskesmas, this community participation can be seen in table 4 where the low level of participation of the elderly in implementing the posyandu when compared to the number of elderly people in the Jua Gaek Puskesmas work area. In addition, the understanding of the program can also be measured to what extent the community understands program activities and the extent to which the community has attended and received the program socialization. Another cause is the absence of community participation/presence in the program socialization held by the puskesmas together with the elderly Posyandu cadres and teams.

In improving the implementation of the posyandu program for the elderly, cooperation from all parties is needed, not only from the puskesmas, village midwives and cadres, the role of the community is also needed so that this program can run properly. If the community plays an active role in the success of this program by helping each other and reminding and providing an understanding of the importance of health for our parents, even helping to deliver it and by always reminding the elderly to come to the Puskesmas, this program will be a success. The participation of the elderly population in the elderly posyandu program at the Puskesmas Jua Gaek can be seen in the following table: 
Table 4 Elderly Participation in Elderly Posyandu at Work Area of Puskesmas Jua Gaek in 2019

\begin{tabular}{clccc}
\hline No & Name of Jorong & Total Elderly & Participation of the elderly & Percentage \\
\hline 1 & Pasar Usang & 278 & 73 & $26,2 \%$ \\
2 & Pasar Baru & 418 & 193 & $46,2 \%$ \\
3 & Panyalai & 462 & 80 & $17,3 \%$ \\
4 & Balai Tangah & 231 & 87 & $37,7 \%$ \\
5 & AA Sonsang & 291 & 130 & $44,7 \%$ \\
6 & Balai Pandan & 491 & 170 & $34,6 \%$ \\
7 & Sungai Rotan & 736 & 181 & $24,6 \%$ \\
8 & Sawah Taluak & 358 & 151 & $42,2 \%$ \\
9 & Tangah Padang & 281 & 87 & $31,0 \%$ \\
& Total & $\mathbf{3 5 4 6}$ & $\mathbf{1 1 5 2}$ & $\mathbf{3 2 , 5 \%}$ \\
\hline
\end{tabular}

Source : Data of Puskesmas Jua Gaek,2019

From table 4 it can be seen that the participation rate of the elderly coming to the elderly posyandu in 2019 was only $32.5 \%$, namely as many as 1152 people from the number of elderly in the work area of the Jua Gaek Puskesmas, which amounted to 3546 people and this number has not reached the target. From the description of table 4 above, it can be seen that the participation rate of the elderly in joining the posyandu is still below $50 \%$, which means that the level of participation in the elderly is still low.

Second, right on target. A program is said to be effective if the program has been able to achieve predetermined goals. This program has been right on target, the target is elderly, there are three groups of elderly age groups who are the targets of this elderly posyandu program, namely those aged 45-59 years, 59-69 years and ages 70 and over. The target is correct for the elderly in the work area of the Jua Gaek Posyandu but they have not reached the target because the participation rate of the elderly in coming to the posyandu is still low.

In the implementation of the elderly posyandu in December 2019, the participation of the elderly in elderly posyandu activities based on age group in the Jua Gaek Puskesmas work area can be seen in the table below: 
Table 5 Elderly Visits in the Elderly Posyandu in Work Area of the Jua Gaek Posyandu Based on Age Group as of December 2019

\begin{tabular}{|c|c|c|c|c|c|c|c|c|c|c|c|c|c|c|c|}
\hline \multirow{2}{*}{ No } & \multirow{2}{*}{$\begin{array}{c}\text { Name } \\
\text { of } \\
\text { Jorong }\end{array}$} & \multicolumn{6}{|c|}{ Target of Elderly } & \multirow{2}{*}{$\begin{array}{c}\text { Total } \\
\text { Target } \\
\text { of } \\
\text { Elderly }\end{array}$} & \multicolumn{4}{|c|}{$\begin{array}{c}\text { Visiting Elderly } \\
60-69\end{array}$} & \multicolumn{2}{|c|}{$>70$} & \multirow{2}{*}{$\begin{array}{c}\text { Total } \\
\text { Visiting o } \\
\text { Elderly }\end{array}$} \\
\hline & & $\mathbf{M}$ & $\mathbf{F}$ & $\mathbf{M}$ & $\mathbf{F}$ & $\mathbf{M}$ & $\mathbf{F}$ & & M & $\mathbf{F}$ & $\mathbf{M}$ & $\mathbf{F}$ & M & $\mathbf{F}$ & \\
\hline 1 & $\begin{array}{l}\text { Pasar } \\
\text { Usang }\end{array}$ & 56 & 70 & 61 & 51 & 15 & 25 & 278 & 0 & 0 & 0 & 0 & 0 & 0 & 0 \\
\hline 2 & $\begin{array}{l}\text { Pasar } \\
\text { Baru }\end{array}$ & 102 & 123 & 50 & 67 & 36 & 40 & 418 & 0 & 0 & 2 & 0 & 2 & 2 & 6 \\
\hline 3 & Panyalai & 119 & 141 & 64 & 72 & 29 & 37 & 462 & 3 & 0 & 0 & 1 & 0 & 1 & 5 \\
\hline 4 & $\begin{array}{l}\text { Balai } \\
\text { Tangah }\end{array}$ & 42 & 51 & 34 & 42 & 28 & 34 & 231 & 0 & 0 & 0 & 1 & 0 & 1 & 2 \\
\hline 5 & $\begin{array}{l}\text { AA } \\
\text { Sonsang }\end{array}$ & 76 & 64 & 41 & 48 & 48 & 14 & 291 & 36 & 48 & 8 & 12 & 1 & 4 & 109 \\
\hline 6 & $\begin{array}{l}\text { Balai } \\
\text { Pandan }\end{array}$ & 149 & 152 & 64 & 53 & 25 & 48 & 491 & 6 & 2 & 3 & 5 & 0 & 0 & 16 \\
\hline 7 & $\begin{array}{l}\text { Sungai } \\
\text { Rotan }\end{array}$ & 214 & 247 & 88 & 104 & 23 & 60 & 736 & 0 & 0 & 0 & 0 & 0 & 0 & 0 \\
\hline 8 & $\begin{array}{l}\text { Sawah } \\
\text { Taluak }\end{array}$ & 109 & 98 & 45 & 48 & 15 & 43 & 358 & 0 & 0 & 0 & 0 & 0 & 0 & 0 \\
\hline 9 & $\begin{array}{l}\text { Tangah } \\
\text { Padang } \\
\end{array}$ & 73 & 80 & 31 & 48 & 21 & 28 & 281 & 6 & 8 & 4 & 6 & 1 & 6 & 31 \\
\hline & Total & \multicolumn{2}{|c|}{$\begin{array}{c}884 \quad 956 \\
1.840\end{array}$} & $\begin{array}{r}417 \\
8 \\
\%\end{array}$ & 482 & \multicolumn{2}{|c|}{225} & 3.268 & $\begin{array}{r}51 \\
1 \\
5,77 \\
5 \\
\end{array}$ & $\begin{array}{l}9^{58} \\
6,07 \\
2^{6,07} \\
\end{array}$ & $\begin{array}{r}17 \\
4,08 \\
\end{array}$ & $\begin{array}{l}25 \\
5,19 \\
7\end{array}$ & $\begin{array}{r}4 \\
1,78 \\
\end{array}$ & $\begin{array}{r}14 \\
4,61\end{array}$ & $\begin{array}{r}169 \\
5,17\end{array}$ \\
\hline
\end{tabular}

Source: Processed from data of the Jua Gaek Puskesmas, 2019

From table 5 it is known that the target elderly of the 3,268 people, but only 169 people or $5.17 \%$ involved the elderly posyandu program in December 2019 in the Jua Gaek Puskesmas work area. This was followed by a decrease in the visit rate of the elderly population based on age group and sex. The rate of elderly visits in the implementation of the posyandu for elderly at the Jua Gaek Posyandu in December 2019, shows that the population of the 45-59 age category visited with the highest proportion of $5.92 \%$ or 109 people compared to the 59- 69 years and $>70$ years age group. However, the proportion of visits is still in a very low category because it does not reach $30 \%$ of the population in the $45-59$ year age group who live 1,840 elderly targets in December 2019, the same condition also occurs in the 59-69 years and $>70$ years age category. Meanwhile, if you look at the total visits of the elderly from 9 jorong / villages in the Jua Gaek Puskesmas work area in 2019 each month can be seen in the following table 6: 
Table 6 Elderly Visits by Age Group at Elderly Posyandu in the area of the Jua Gaek Puskesmas every month in 2019

$\begin{array}{clcccc}\text { No } & \text { Month } & \mathbf{4 5 - 5 9} & \begin{array}{c}\text { Age Group } \\ \mathbf{5 9 - 6 9}\end{array} & \mathbf{> 7 0} & \text { Total } \\ 1 & \text { January } & 108 & 56 & 38 & \mathbf{2 0 2} \\ 2 & \text { February } & 97 & 53 & 38 & \mathbf{1 8 8} \\ 3 & \text { March } & 112 & 76 & 53 & \mathbf{2 4 1} \\ 4 & \text { April } & 135 & 53 & 29 & \mathbf{2 1 7} \\ 5 & \text { May } & 108 & 89 & 49 & \mathbf{2 4 6} \\ 6 & \text { June } & 36 & 26 & 12 & \mathbf{7 4} \\ 7 & \text { July } & 99 & 67 & 45 & \mathbf{2 1 1} \\ 8 & \text { August } & 99 & 67 & 45 & \mathbf{2 1 1} \\ 9 & \text { September } & 64 & 46 & 26 & \mathbf{1 3 6} \\ 10 & \text { October } & 159 & 105 & 80 & \mathbf{3 4 4} \\ 11 & \text { November } & 134 & 33 & 33 & \mathbf{2 0 0} \\ 12 & \text { December } & 109 & 42 & 18 & \mathbf{1 6 9}\end{array}$

From table 6, it is known that the most elderly visits in the implementation of the posyandu for the elderly in the Jua Gaek Puskesmas work area were mostly in October 2019, namely 344 elderly people. If further analyzed, the number of elderly visits is still low for the level of program targeting because the number of elderly people who were targeted was 3,268 people but not followed by the participation of the elderly who participated in the posyandu program.

Third, be on time. This can be seen from the use of time in the implementation of the previously planned programs, whether it is in accordance with the set time or not. The planning of the posyandu program for the elderly at the Jua Gaek Puskesmas is held regularly once a month after the implementation of the posyandu for toddlers. From the 2019 data that the author obtained from the Jua Gaek Puskesmas, the implementation of the elderly posyandu is carried out every month in the third week and is carried out regularly after the implementation of the posyandu for toddlers. The implementation of posyandu activities for the elderly at the Jua Gaek Puskesmas apart from being carried out regularly every month on the third week, is also carried out every month in nine jorong in the Jua Gaek Puskesmas working area. This shows that the elderly posyandu program implemented in the Jua Gaek Puskesmas work area can be said to be on time in implementation and in accordance with the program planning at the Jua Gaek Puskesmas.

Fourth, the achievement of goals.A program is said to be effective measured by achieving the objectives of activities carried out in accordance with predetermined goals. The purpose of this posyandu program for the elderly is to record the health status and improve the quality of services for the elderly and their health and to try to prevent and detect diseases of the elderly so that they can achieve a happy and efficient old age in social life. Based on data on the health status of the elderly community in the working area of Jua Gaek Puskesmas, which is seen from the morbidity rate, especially in the elderly and high-risk group, namely $>60$ years old, it shows that the performance of Jua Gaek Puskesmas officers are in a good category because data collection is carried out every month according to types of diseases suffered by the elderly. Data on morbidity reports on elderly health services at the Jua Gaek Puskesmas recapitulated in 2019 can be seen as follows 
Table 7 Morbidity Data for Elderly Health Services at Jua Gaek Puskesmas Based on the type of disease in January - December 2019

\begin{tabular}{llccccccccccccc}
\hline \multirow{2}{*}{ No } & Name of disease & $\mathbf{1}$ & $\mathbf{2}$ & $\mathbf{3}$ & $\mathbf{4}$ & $\mathbf{5}$ & $\mathbf{6}$ & $\mathbf{7}$ & $\mathbf{8}$ & $\mathbf{9}$ & $\mathbf{1 0}$ & $\mathbf{1 1}$ & $\mathbf{1 2}$ & $\begin{array}{c}\text { Total in } \\
\mathbf{2 0 1 9}\end{array}$ \\
\hline 1 & Mental disorders & 6 & 1 & 6 & 6 & 2 & 1 & 15 & 15 & 7 & 10 & 5 & 3 & $\mathbf{7 7}$ \\
2 & 2 & 0 & 9 & 21 & 37 & 13 & 8 & 8 & 8 & 11 & 32 & 17 & $\mathbf{1 6 6}$ \\
& BMI & & & & & & & & & & & & & \\
& Blood pressure & 6 & 18 & 5 & 1 & 4 & 6 & 1 & 1 & 1 & 62 & 61 & 4 & $\mathbf{1 7 0}$ \\
3 & a. Low & 46 & 30 & 46 & 58 & 53 & 31 & 84 & 84 & 30 & 119 & 58 & 59 & $\mathbf{6 9 8}$ \\
& b. Height & 0 & 0 & 0 & 0 & 0 & 0 & 0 & 0 & 0 & 0 & 0 & 0 & $\mathbf{1 0 8}$ \\
& (Hypertension) & 16 & 7 & 23 & 35 & 30 & 11 & 10 & 10 & 0 & 19 & 0 & 0 & $\mathbf{1 6 1}$ \\
4 & Anemia & 11 & 5 & 11 & 19 & 9 & 6 & 9 & 9 & 3 & 13 & 13 & 11 & $\mathbf{1 1 9}$ \\
5 & Cholesterol & 12 & 23 & 36 & 47 & 52 & 15 & 20 & 20 & 2 & 0 & 0 & 1 & $\mathbf{2 2 8}$ \\
6 & DM & 0 & 0 & 2 & 0 & 0 & 0 & 2 & 2 & 0 & 0 & 0 & 0 & $\mathbf{6}$ \\
7 & Uric acid & 0 & 0 & 1 & 5 & 2 & 0 & 0 & 0 & 0 & 0 & 0 & 0 & $\mathbf{8}$ \\
8 & Kidney disorders & 19 & 0 & 8 & 12 & 7 & 1 & 31 & 31 & 11 & 90 & 15 & 0 & $\mathbf{2 2 0}$ \\
9 & Cognitive Disorders & 11 & 2 & 7 & 13 & 5 & 3 & 13 & 13 & 3 & 36 & 7 & 1 & $\mathbf{1 1 4}$ \\
10 & Vision Impairment & $\mathbf{1 2 9}$ & $\mathbf{8 6}$ & $\mathbf{1 5 4}$ & $\mathbf{2 1 7}$ & $\mathbf{2 0 1}$ & $\mathbf{8 7}$ & $\mathbf{1 9 3}$ & $\mathbf{1 9 3}$ & $\mathbf{6 5}$ & $\mathbf{3 6 0}$ & $\mathbf{1 9 1}$ & $\mathbf{9 6}$ \\
11 & Hearing disorders & \multicolumn{1}{c}{ Total } & Source: Processed from data of the Jua Gaek Puskesmas, 2019 & &
\end{tabular}

Table 7 shows the health data for the elderly $>60$ years old who participated in the monthly Posyandu activities for the elderly in 2019 from 9 jorong / villages in the Jua Gaek Puskesmas working area. From table 7 it can be seen that the disease most commonly suffered by the elderly in the work area of the Jua Gaek Posyandu in 2019 is hypertension as 698 people. Data collection on the health status of the elderly population requires efforts to increase the overall health data collection for the elderly population, this is because the number of elderly residents in the work area of Jua Gaek Posyandu reaches 3,268 people as can be seen in table 5 .

Fifth, real change. Measured through how big that program, it can have an effect and can change the situation for the better in real terms for the community. So, the posyandu program for the elderly if we linked with changes that occur from program implementation can be ignored that these changes have not been fully felt by the elderly community in the working area of the Jua Gaek Health Centre. This is because the target of the elderly is not proportional to the number of visits or the level of participation of the elderly in every elderly posyandu activity carried out in 9 jorong. The elderly who regularly come to the posyandu can experience changes because every elderly health check always follows actions that are treated directly or directed to a higher health facility such as a hospital. In addition to the treatment given to the elderly who participate in the posyandu for the elderly, the Jua Gaek Health Center also provides facilities in the form of counseling. Even during the Covid-19 pandemic, Jua Gaek Puskesmas cadres made direct visits to elderly homes or by telephone.

\section{Constraints in the Implementation of the Elderly Posyandu in Work Area of Jua Gaek Puskesmas}

According Hansen and Mowen cited Selviana[7], constraint factors are grouped into two, That is internal constraints and external constraints. Internal constraints are the limiting factors and systems originating from the organization while external factors are the factors that limit the organization that comes from outside organization. Stacles from implementing the posyandu program for the elderly at the Jua Gaek Puskesmas can be mapped as follows: 
a. Internal Constraints

Internal constraints in the implementation of posyandu for elderly in the working area of the Jua Gaek Puskesmas are constraints in the availability of facilities and infrastructure. Limited facilities are related to the availability of medical checkup equipment at the posyandu. The facilities still have to be taken from the puskesmas to the posyandu in 9 jorong which is the working area of the Jua Gaek Puskesmas. Meanwhile, the constraints in terms of infrastructure are related to the limited number of special posts to organize the posyandu for the elderly in every jorong.

b. Eksternal Constrants

The biggest obstacle in implementing posyandu for elderly in the working area of Jua Gaek Puskesmas is external constraints, especially environmental factors. Environmental factors are related to the environment in the Jua Gaek area which is a rural area and depends on agriculture, making the people in the Jua Gaek area more concerned with their work in the agricultural sector than coming to the posyandu. Apart from environmental factors, the elderly residents' fear of knowing the disease they are suffering from is also a problem in their level of participation in posyandu. Even the family cannot force their elderly families to come to the posyandu.

Based on the above constraints, it can be seen that the obstacles in organizing posyandu for elderly in the Jua Gaek area are more due to external factors. Internally as the implementer of the elderly posyandu program, Puskesmas Jua Gaek has appointed cadres to implement the program in 9 jorong in the area and conduct socialization about the elderly posyandu program to the community. Even though they are constrained by the availability of facilities and infrastructure, the activities of the elderly posyandu in the work area of Jua Gaek Puskesmas are still carried out regularly every month even though in the Covid-19 conditions. Meanwhile, support for program implementation is constrained by community participation, both for participation in program socialization and in visits to posyandu. In addition, the family factor where the elderly residents live also cannot force the presence of the elderly population in implementing the posyandu. This ultimately results in low data on the health status of the elderly population in the Jua Gaek area.

\section{Efforts to Improve the Implementation of the Elderly Posyandu in the Work Area of Jua Gaek Puskesmas}

The efforts made by the Jua Gaek Health Center in improving the implementation of the posyandu program for the elderly in its working area were to do "GERTAK" (simultaneous movements) carried out by the Puskesmas and the team and cadres in the afternoon by visiting the elderly's home directly. This activity is carried out in the context of daily health checks. Efforts made for those who did not attend by being visited directly to their homes were also made to remind the community to be involved in the posyandu for the elderly. Various activities to socialize the posyandu program for the elderly and to increase community involvement were carried out such as post-wirid socialization at the mosque, PKK activities in the area and visiting the community directly.

Meanwhile, during the Covid-19 pandemic the elderly posyandu was not held in person but was held online. Technically, the cadres recorded at the elderly's house to be asked for a number that could be contacted to carry out online control, which was carried out by a team from the puskesmas with several questions related to the daily activities of the elderly and the problems of their health. If the elderly have changes in their health, they will be advised to come directly to the health center to be treated, but if there is no problem, they can only take regular medicines 
for consumption, they can be represented by their families. This activity is also carried out once a month in accordance with the usual elderly posyandu. This has been implemented since April 2020, but not everything can be controlled online because there are still a lot of data from cadres that have not been received by the puskesmas. This data can be seen in the following table:

Table 8 Number of Elderly People Who Can Be Controlled Online During Covid-19 in April-June 2020

\begin{tabular}{|c|c|c|c|c|}
\hline No & Name of Jorong & April & May & June \\
\hline 1 & Pasar Usang & 2 & 0 & 0 \\
\hline 2 & Pasar Baru & 0 & 7 & 15 \\
\hline 3 & Panyalai & 0 & 0 & 27 \\
\hline 4 & Balai Tangah & 0 & 0 & 0 \\
\hline 5 & AA Sonsang & 12 & 6 & 11 \\
\hline 6 & Balai Pandan & 11 & 5 & 9 \\
\hline 7 & Sungai Rotan & 7 & 4 & 0 \\
\hline 8 & Sawah Taluak & 17 & 13 & 15 \\
\hline \multirow[t]{2}{*}{9} & Tangah Padang & 11 & 7 & 9 \\
\hline & Total & 60 & 47 & 86 \\
\hline
\end{tabular}

Source : Data of Puskesmas Jua Gaek, 2020

On table 8 above, it can be seen that not all elderly registered at the Jua Gaek Puskesmas can be contacted online to do daily checks by the puskesmas as a substitute due to the elimination of direct implementation of the posyandu elderly program during Covid-19. This online check has been conducted from April to June 2020 and in April 2020 there were 60 people who could be contacted, while in May 2020 only 42 people. This means less than the previous month. However, in June 2020 there was an increase of 86 people.

\section{Conclusion}

Based on the explanation of the writing above, there are several important things that are the conclusions of this paper as follows:

a. The implementation of the posyandu program for the elderly in the working area of the Jua Gaek Puskesmas cannot be said to be effective because many factors have not been achieved, such as many people who do not understand the elderly posyandu program. The target of the elderly posyandu has not reached the target so that the goal has not been fully achieved and there has not been any change that has occurred with the holding of the posyandu for the elderly due to the lack of seriousness of the elderly in participating in activities and attending the posyandu.

b. As for the obstacles in the implementation of the posyandu for the elderly in the working area of the Jua Gaek Puskesmas are as follows: the first, internal constraints, namely that the medical devices used are adequate but cannot be placed in every jorong and are still taking turns and there is also no special post for conducting posyandu . Second, external obstacles in the implementation of the elderly posyandu in the work area of Jua Gaek Puskesmas are environmental factors that make the elderly people work rather than coming to the posyandu and family support where the elderly 
residents live who are still lacking in coercing or delivering their elderly families to posyandu.

c. One of the efforts made to improve the implementation of the posyandu program for the elderly in the working area of the Jua Gaek Community Health Center is by doing "GERTAK" (simultaneous movements) in the afternoon. The puskesmas together with cadres came to the elderly's house to carry out routine checks. This direct visit was also intended as a socialization to the community about the elderly posyandu program. While the efforts made during the Covid-19 pandemic, the implementation of the elderly posyandu was not carried out directly but was carried out online by contacting via telephone. This online activity is still carried out once a month.

\section{Recommendations}

In accordance with the description of the analysis of the implementation of the elderly posyandu in the working area of the Jua Gaek Puskesmas, the following Recommendations are proposed:

a. To make the posyandu program for the elderly in the working area of the Jua Gaek Health Center a success, it is hoped that there will be cooperation from all parties, not only the community health center, cadres and the elderly but also the community and elderly families to help each other remind and provide knowledge about the importance of attending the elderly posyandu.

b. Socialization of the elderly posyandu program is not only carried out through wirid at mosques, arisan, PKK activities and other community events but is also carried out in other ways and is right on target such as placing banners or billboards about elderly posyandu, via radio, social media because of the population category seniors ranging from pre-advanced age 45 years and over. Other socialization can be done by using a mobile health center car to jorong-jorong in the Jua Gaek Puskesmas working area.

\section{References}

[1] M. G. and I. P. Nilasari, "Evaluasi Peraturan Daerah Kota Surabaya Nomor 3 Tahun 2014 Tentang Kesejahteraan Lanjut Usia (Studi Pada Posyandu Lansia Sekar Melati di Rw II Kelurahan Baratajaya Kecamatan Gubeng Kota Surabaya)," 2017, [Online]. Available: http//jurnalmahasiswa.unesa.ac.id .

[2] BPS, "Statistik Penduduk Lanjut Usia 2019," Jakarta, Indonesia, 2019.

[3] Taufiqurakhman, Kebijakan Publik Pendelegasian Tanggung jawab Negara kepada Presiden selaku Penyelenggara Pemerintahan. Jakarta: Universitas Moestopo Beragama Pers, 2014.

[4] S. N. Kholifah, "Keperawatan Gerontika Komprehensif.," 2016.

[5] Ministry of Health of the Republic of Indonesia, "Profil Kesehatan Indonesia 2018," Jakarta, 2018.

[6] I. Lestari, Rini Puji and Murti, "Efektifitas Program Nasional Pemberdayaan Masyarakat Mandiri (PNPM Mandiri) Studi Kasus di Desa Sedengan Mijen Kecamatan Krian Kabupaten Sidoarjo," J. Penelit. Adm. Publik. JPAP, vol. 1 No 1, 2015.

[7] R. Selviana, Valuasi Ekonomi Objek Wisata Situs Karangkamulyan di Kabupaten Ciamis: Pendekatan Biaya Perjalanan (Travel Cost Method). Skripsi. Yogyakarta: Fakultas Ekonomi Universitas Muahammadiyah, 2016. 